\title{
粒子破砕を考慮した地すべりの流動化メカニズムと運動範囲予測 Sliding mechanism and motion prediction of flowslides in crushable soils
}

\author{
汪 発武a)* ・佐々恭二 ${ }^{\text {b) }} \cdot$ 松本樹典 ${ }^{\text {a) }} \cdot$ 奥野岳志 ${ }^{a}$ \\ Fawu WANG, Kyoji SASSA, Tatsunori MATSUMOTO and Takeshi OKUNO
}

\begin{abstract}
The statistical relationship between landslide volume and apparent friction coefficient shows that grain-crushing phenomenon takes an important role in causing landslide fluidization. This aspect is verified through a series of undrained triaxial tests on soils with different grain crushing susceptibility in this paper. Then, based on experimental results of ring-shear tests, a model for change in the apparent friction coefficient during landslide motion is proposed. The model has been introduced to Sassa's "landslide motion model" for landslide motion prediction. Case studies conducted on the Sumikawa landslide and the Hiegaeshi landslide show that the improved "landslide motion model" could be an effective tool for landslide disaster prevention especially in the crushable soils.

Key words : flowslides, grain crushing, undrained shearing, apparent friction coefficient, motion prediction

\section{和文要旨}

地すべりの体積と見かけの摩擦係数との統計関係より，粒子破砕現象の流動性地すべりに与える影響が重要であることが示唆さ れている。本論文では，異なる粒子破砕性試料に対して，三軸非排水せん断試験を実施し，粒子破砕性と見かけの摩擦係数との関 係を検証した。実験結果によって“すべり面見かけの摩擦係数変化モデル”を提案し，“地すべり運動モデル”に導入することによっ て, 地すべり運動範囲予測法の改良を行った。破砕性斜面で発生した澄川地すべり及び稗返地すべりに対する運動シミュレーショ ンの事例研究より，改良した“地すべり運動モデル”の有効性が証明された。

キーワード：流動性地すべり，粒子破砕, 非排水せん断, 見かけの摩擦係数, 運動範囲予測
\end{abstract}

\section{1.まえがき}

地震及び豪雨などによって，土砂災害がしばしば引き 起こされている。特に流動性地すべりのような高速土砂 流動現象は運動速度が速く，移動距離が大きいため，大 きな災害をもたらすことが多い。近年都市地域でも目立 つようになっている流動性斜面災害を防止するために, 平成13年 4 月 1 日から“土砂災害警戒区域等における土 砂災害防止対策の推進に関する法律”が施行された。こ のような背景の中で, 防災の観点から, 長距離・高速運 動地すべりの運動機構を解明することが要求され, 運動 機構を解明した上での地すべり運動予測法の開発が急務 とされている。

これまでに，高速土砂流動現象の影響素因について， 地盤の相対密度, 細粒分の含有率, 斜面形状などが指摘 されてきた（Cubrinovski and Ishihara, 1998)。地すべ り発生事例を統計的に見ると, 地すべりの流動性は地す ベり土塊の体積にも関係している（奥田，1984；Sassa, 1988)。図-1は，地すべりの見かけの摩擦係数と運動 土塊の体積の統計関係を示したものである。見かけの摩 擦係数は斜面の高さと流下距離の比で表される。体積の 大きい地すべりほど，見かけの摩擦係数が小さくなって いる。日本で近年発生した流動性地すべりはほとんど安

\footnotetext{
* 連絡著者/corresponding author

a) 金沢大学工学部土木建設工学科

Department of Civil Engineering. Faculty of Engineering, Kanazawa University 厂 920-8667 金沢市小立野2-40-20

2-40-20, Kodatsuno, Kanazawa, 920-8667, Japan

b) 京都大学防災研究所斜面災害研究センター Research Centre on Landslides, Disaster Prevention Research Institute, Kyoto Uni-
versity
}

山岩質斜面，火山灰斜面，あるいは風化花崗岩斜面で発 生しており，体積の小さいものでも高い流動性を示して いる (Sassa et al., 1996; Wang et al., 2002)。地すべり の体積が大きいほど，すべり面に作用する垂直応力が大 きくなることが容易に推定される。高速土砂流動現象は 主に飽和地盤において発生する非排水せん断現象である ことが明らかになっている (Hutchinson and Bhandari, 1971)。また, Sassa et al. (1996) がリングせん断試験 装置を用いて，粒子破砕による“すべり面液状化”が高 速運動地すべりの原因の一つであることを解明した。本

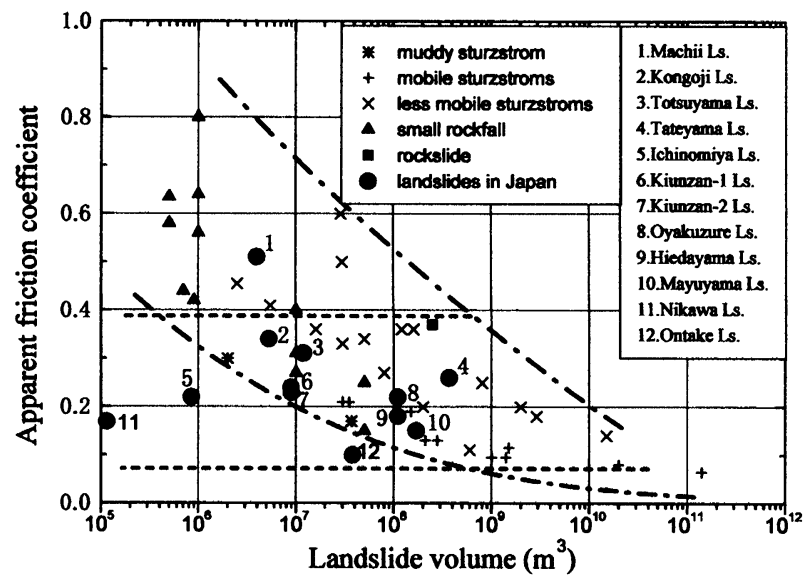

図ー1 見かけの摩擦係数と地すべり体積との関係（奥田， 1984 ; Sassa, 1998に加筆)

Fig. 1 Relationship between landslide volume and apparent friction coefficient (Modified from Okuda, 1984 and Sassa, 1988) 
研究では予備実験で判明した粒子破砕性の異なる試料を 用いて，異なる初期有効拘束圧で圧密非排水三軸せん断 試験を実施し，応力レベルによる高速運動地すべりへの 影響を解明することを目的にした。ついで，すべり面見 かけの摩擦係数変化モデルを考案し, それをSassa (1988) によって提案された地すべり運動モデルに導入すること によって，地すべり運動予測システムを改良する。最後 に，1997年に発生した秋田県澄川地すべり及び1998年豪 雨によって発生した福島県西郷村稗返地すべりを例とし て，破砕性斜面で発生した地すべりの運動シミュレー ションを行い，流動性地すべりの運動範囲予測の可能性 を示す。

\section{2．地すべり土塊の破砕性と流動性に関する三軸非排水 せん断試験}

\section{1 試験方法と手順}

本研究で用いた試料は豊浦硅砂 (TYS), 市販建築材 料用の硅砂 7 号 (SS 7 ), 流動性地すべりの発生しやす い九州地方から採取したしらす (SRS)，1998年豪雨に よって発生した福島県稗返地すべりの源頭部で採取した 火山灰質土（HGS）である。図－２は各試料の粒径加積 曲線を表し, 表 -1 に各試料の最大・最小密度, 平均粒 径, 均等係数及び土粒子比重をまとめている。

\section{2 圧密非排水三軸せん断試験}

圧密非排水三軸せん断試験は，各試料に対して，98 $\mathrm{kPa}, 196 \mathrm{kPa}, 294 \mathrm{kPa}$ の異なる初期有効拘束圧で行っ た。砂地盤の初期密度による液状化への寄与が明らかに なってきているが (Ishihara, 1993)，本研究では粒子破 砕性による非排水せん断挙動への影響を調べるために, 試料ごとに, 各拘束圧で圧密後（せん断直前）の相対密 度がほぼ一定になるように，試料の初期密度を調整した。

供試体は煮沸した試料を水中落下し，負圧法により作 成した。供試体の初期高さは $100 \mathrm{~mm}$, 直径は $50 \mathrm{~mm}$ であ る。一旦 $50 \mathrm{kPa}$ で圧密した後，間隙水圧係数 $B$ 值を計測 した。 $B$ 值は非排水状態における間隙水圧増分 $\Delta u$ の拘

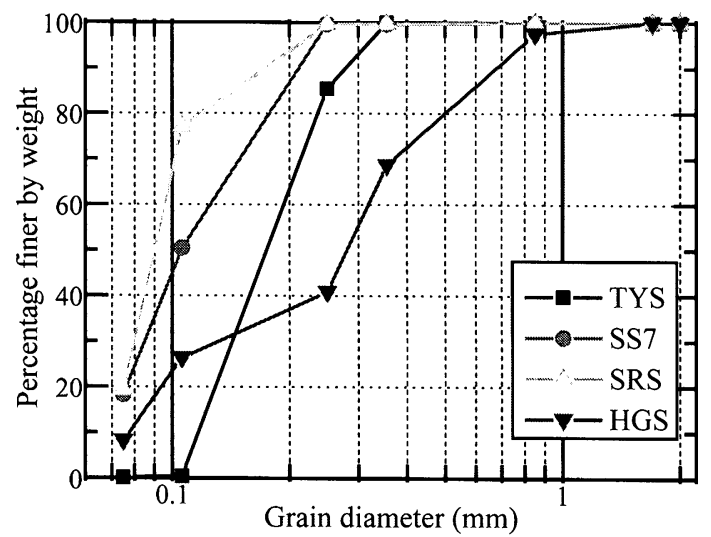

図一2 非排水三軸せん断試験で用いた試料の粒径加積曲線

Fig. 2 Grain size distribution curves of the soil samples used in undrained triaxial shear tests
表ー 1 用いた試料の物理特性

\begin{tabular}{|l|c|c|c|c|c|}
\hline & $\begin{array}{c}\text { 最大 } \\
\text { 密度 } \\
\left(\mathrm{t} / \mathrm{m}^{3}\right)\end{array}$ & $\begin{array}{c}\text { 最小 } \\
\text { 密度 } \\
\left(\mathrm{t} / \mathrm{m}^{3}\right)\end{array}$ & $\begin{array}{c}\text { 平均 } \\
\text { 粒径 } \\
(\mathrm{mm})\end{array}$ & $\begin{array}{c}\text { 均等 } \\
\text { 係数 }\end{array}$ & $\begin{array}{c}\text { 土粒子 } \\
\text { 比重 }\end{array}$ \\
\hline $\begin{array}{l}\text { 豊浦硅砂 } \\
(\mathrm{TYS})\end{array}$ & 1.652 & 1.332 & 0.176 & 1.7 & 2.67 \\
\hline $\begin{array}{l}\text { 硅砂 7 号 } \\
(\mathrm{SS} 7)\end{array}$ & 1.541 & 1.204 & 0.106 & 2.1 & 2.63 \\
\hline $\begin{array}{l}\text { しらす } \\
(\mathrm{SRS})\end{array}$ & 1.356 & 0.976 & 0.090 & 1.6 & 2.43 \\
\hline $\begin{array}{l}\text { 稗返火山灰 } \\
\text { 質土(HGS) }\end{array}$ & 0.923 & 0.711 & 0.281 & 4.1 & 2.64 \\
\hline
\end{tabular}

束圧増分 $\Delta \sigma_{3}$ に対する比 $\Delta u / \Delta \sigma_{3}$ で表す (Skempton, 1954)。 $B$ 值が 0.95 以上であれば，所定の拘束圧まで圧密し，そ の後, 非排水状態で, 軸ひずみ速度 $0.085 \% / \mathrm{min}$ で非排 水せん断を行った。軸ひずみ $\varepsilon_{a}$ が $10 \%$ に達した時点で試 験を終了し，粒子破砕の程度を調べるために，試験後の 試料を用いて粒度分析を行った。そして, Marsal(1967) によって定義された粒子破砕係数 $B_{p}$ （図－3）を求めた。 $B_{p}$ の值が大きいほど，粒子破砕性が大きいことを示す。

図－4は，異なる初期有効拘束圧でせん断した時の各 試料の偏差応力 $t=\left(\sigma_{a}-\sigma_{r}\right) / 2$ ひずみ曲線である。 $\sigma_{a}$ $\left(=\sigma_{1}\right)$ は軸方向の全応力であり, $\sigma_{r}\left(=\sigma_{3}\right)$ は全拘束圧で ある。圧密後の密度はいずれも中密から密であるにもか かわらず，TYSおよびSS7 を用いた試験において，ひず み硬化挙動を示している。図 - 5 は各試験の有効応力経 路を示す。ここで, $s^{\prime}=\left(\sigma_{a}^{\prime}+\sigma_{r}^{\prime}\right) / 2, t=\left(\sigma_{a}-\sigma_{r}\right) / 2$ であ る。 $\sigma_{a}^{\prime}$ は有効軸応力であり， $\sigma_{r}^{\prime}$ は有効拘束圧である。一 見して, TYSは各圧密応力レベルにおいては, せん断 抵抗が比較的高くまで増加していることが分かる。これ に対して，SRS及びHGSはいずれも小さいせん断抵抗を 示している。初期有効拘束圧の影響を明瞭に示すため,

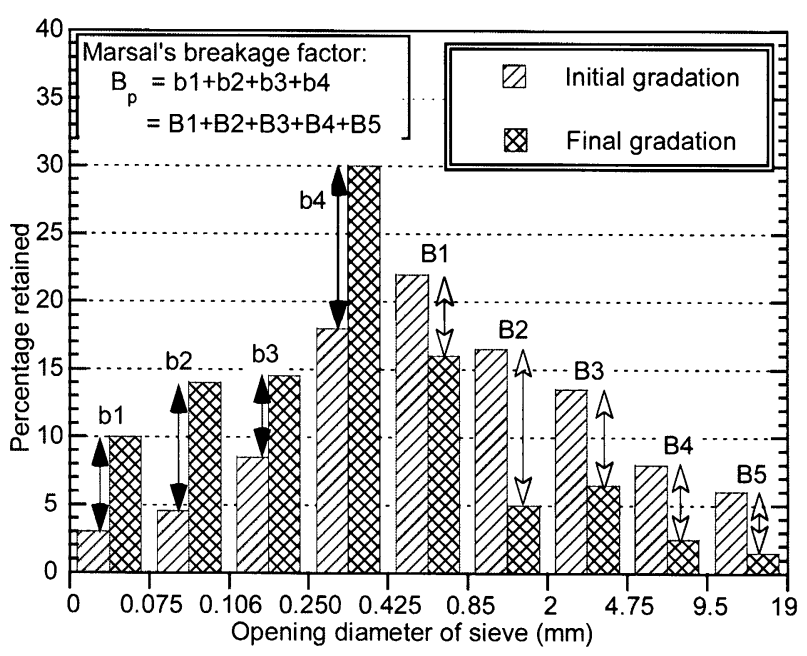

図一 3 Marsal（1967）の粒子破砕係数の定義

Fig. 3 Definition of Marsal's particle breakage factor (Marsal, 1967) 

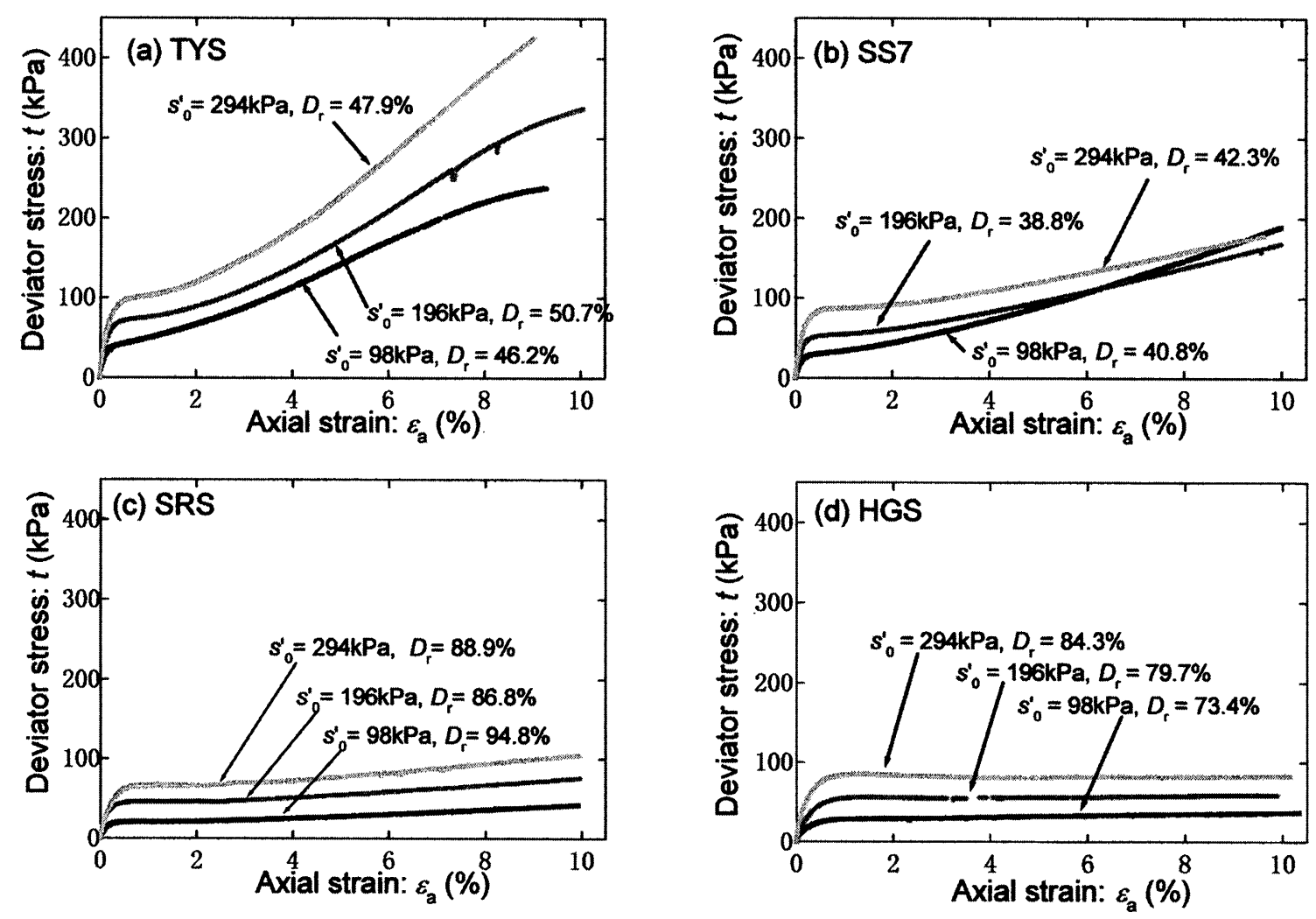

図一４異なる初期有効拘束圧における各試料の偏差応力〜ひずみ曲線

Fig. 4 Stress versus axial strain curves of the four soil samples under different initial effective stresses
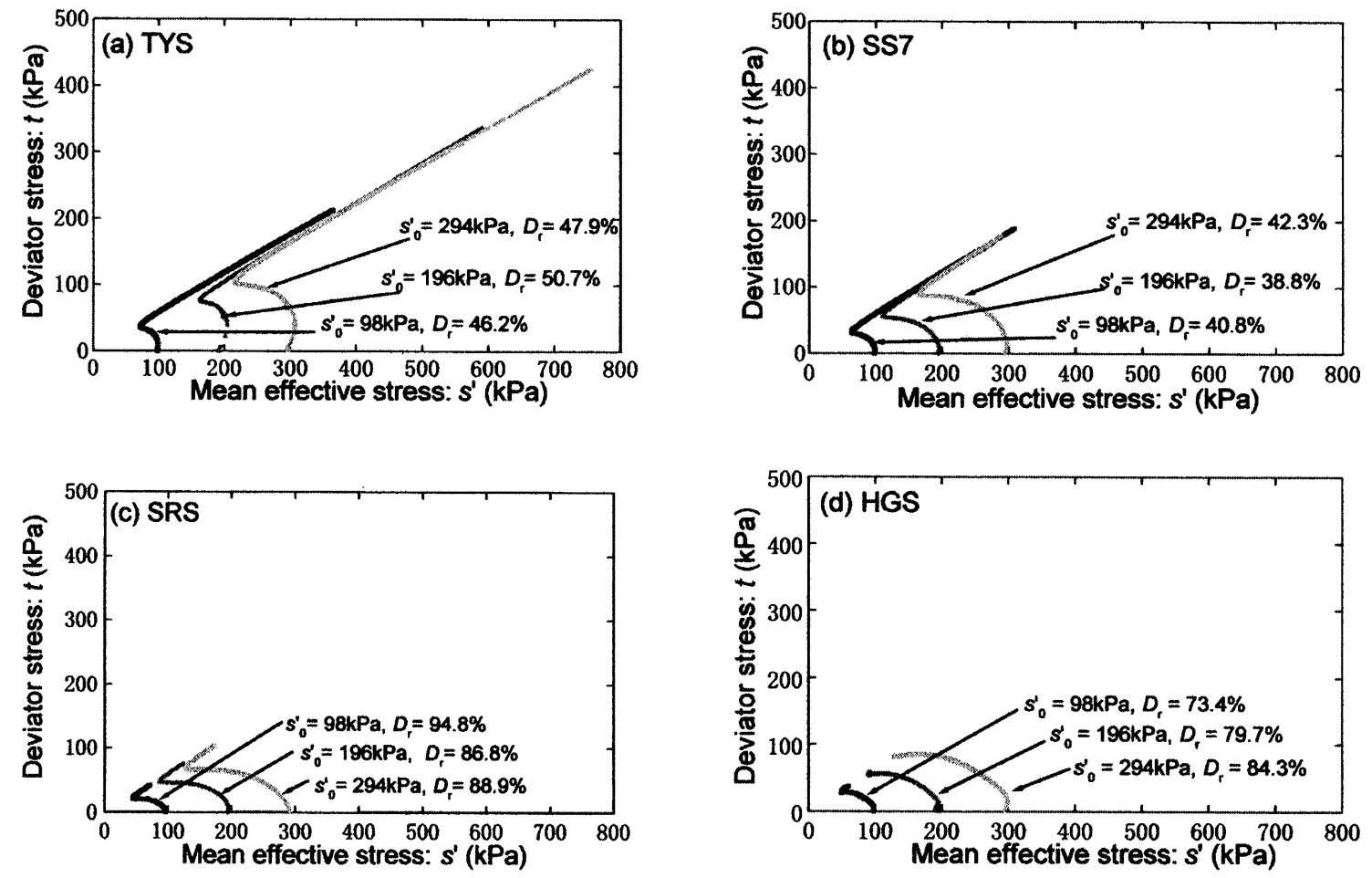

図一 5 異なる初期有効拘束圧における各試料の有効応力経路

Fig. 5 Effective stress paths of the four soil samples in undrained shear tests under different initial effective stresses 
有効応力経路の横軸及び縦軸の座標值を初期有効拘束圧 で除して，正規化した。図ー6は正規化した応力経路を 示す。せん断初期，すなわち破壊線に達するまでは，初 期有効拘束圧 $s_{0}^{\prime}$ による有効応力経路への影響はあまり見 られない。しかし，軸ひずみが10\%に達した最終状態で は，すべての試料において，有効拘束圧が高いほど， $t /$ $s_{0}^{\prime}$ が小さくなっている。また，異なる初期有効拘束圧に よる $t / s_{0}^{\prime}$ の差はSRS及びHGSでは顕著に小さい。中でも， TYS及びSS 7 は有効拘束圧の増大にしたがって, $t / s_{0}^{\prime}$ の 值は顕著に小さくなっている。このことより，これらの 粒子は試験応力のレベルで破砕していることが推定され る。一方, SRS及びHGSは低い有効拘束圧でも， $t / s_{0}^{\prime}$ 值 が小さいことから，98kPaまでの有効拘束圧でも粒子破 砕が十分起こりうることが想定される。因みに，98kPa の拘束圧は, 単位体積重量 $\gamma_{t}=20 \mathrm{kN} / \mathrm{m}^{3}$ の土でできた斜 面の深さ $6 \mathrm{~m}$, 傾斜角 $25^{\circ}$ のすべり面に作用する垂直応 力に相当する。

非排水せん断中の過㮃間隙水圧の挙動を考察するため に，式(1)で表される間隙水圧係数 $A$ を求めた (Skempton, 1954)。

$$
A=\frac{\Delta u-B \cdot \Delta \sigma_{3}}{B \cdot\left(\Delta \sigma_{1}-\Delta \sigma_{3}\right)}
$$

ここで， $B$ は供試体の飽和度を示す間隙水圧係数， $\Delta u$ は発生した過剩間隙水圧， $\Delta \sigma_{1}$ と $\Delta \sigma_{3}$ はそれぞれ非排水状 態における軸応力の増分，拘束圧の増分である。

この間隙水圧係数 $A$ の值が大きいと, 大きな過㮃間隙 水圧が発生したことになる。地すべりに応用すると，地 すべりの流動性が高いことを示唆することになる。図－
7 は各試料の非排水せん断における間隙水圧係数 $A$ の変 化を示す。この結果から, 以下のことが認められる。(1) 初期有効拘束圧が高くなると，間隙水圧係数が大きく なっている；(2) 最終状態では，TYSの間隙水圧係数 が最も小さく，火山灰質試料は圧倒的に大きい。

せん断試験で用いた試料の粒子破砕性を定量的に評価 するために，全ての試験後試料のふるい分け試験を実施 し，未試験の試料の粒度成分と比較することによって， 粒子破砕係数 $B_{p}$ を求め，非排水せん断過程における粒子 破砕の量を調べた。そして，各試験における圧密及びせ ん断エネルギーUとの関係も求めた。三軸試験における 単位体積あたりの圧密及びせん断エネルギーUは式(2)の ように定義される。

$$
U=\sum_{i=1}^{3} \int \sigma_{i}^{\prime} d \varepsilon_{i}
$$

ただし， $\sigma_{1}^{\prime}$ は軸応力, $\sigma_{2}^{\prime}=\sigma_{3}^{\prime}$ は有効拘束圧, $\varepsilon_{1}$ は軸ひ ずみ $\varepsilon_{a}, \varepsilon_{2}=\varepsilon_{3}$ は供試体半径方向のひずみ ひずみ $d \varepsilon_{v}=d \varepsilon_{1}+d \varepsilon_{2}+d \varepsilon_{3}=d \varepsilon_{a}+2 d \varepsilon_{r}$ であることから， 圧密・非排水三軸試験では，式(2)は式(3)のように書き直 せる。

$$
U=\int \sigma_{3}^{\prime} d \varepsilon_{v}+\int\left(\sigma_{1}^{\prime}-\sigma_{3}^{\prime}\right) d \varepsilon_{a}
$$

ここで，右辺第一項は圧密エネルギーであり，第二項 は非排水状態でのせん断エネルギーである。

図-8 はエネルギーUと粒子破砕係数 $B_{p}$ の関係を表し ている。なお，図－8中の $\triangle ， \square$ は有効拘束圧を $98 \mathrm{kPa}$ で一定とし，初期密度を変化させたケースを表す（汪ほ か，2002）。エネルギーによる粒子破砕の程度には違い
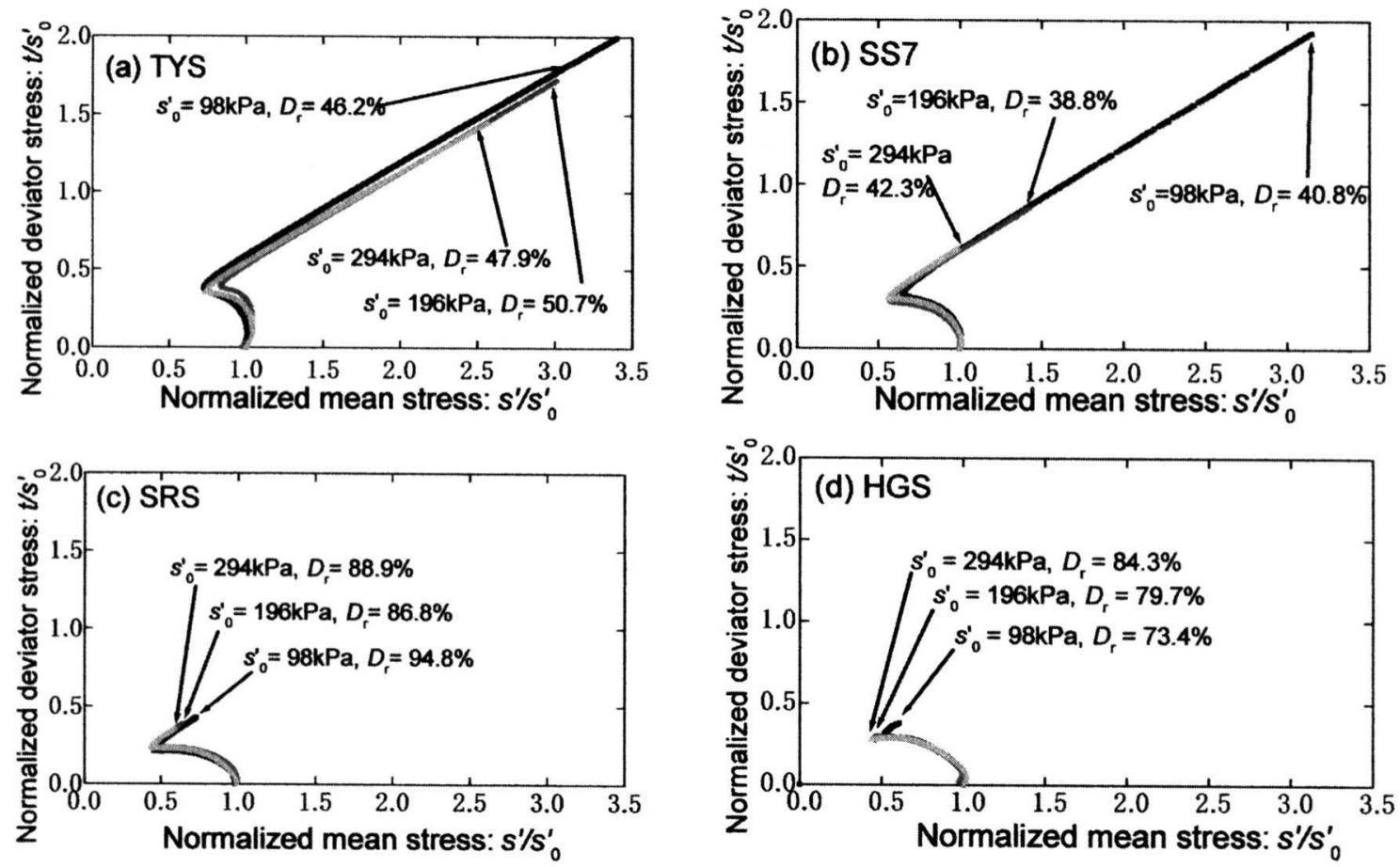

図一 6 異なる初期有効拘束圧における各試料の正規化した有効応力経路

Fig. 6 Normalized effective stress paths of the four soil samples tested in the undrained triaxial shear tests 

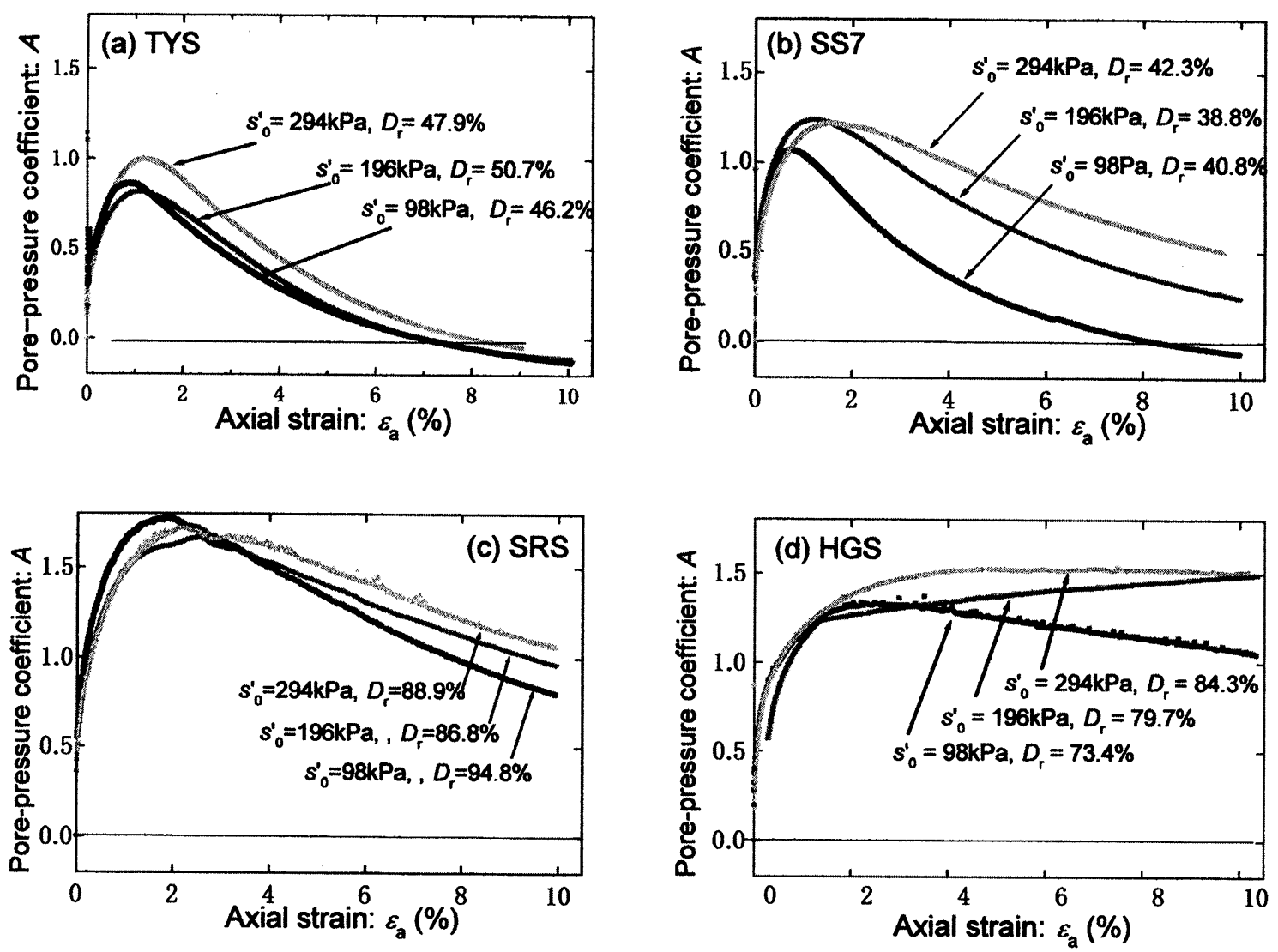

図一 7 異なる初期有効拘束圧における各試料の間隙水圧係数 $\boldsymbol{A}$ ひずみ曲線

Fig. 7 Pore pressure coefficient $\boldsymbol{A}$ versus axial strain curves of the soil samples tested in different initial effective stresses
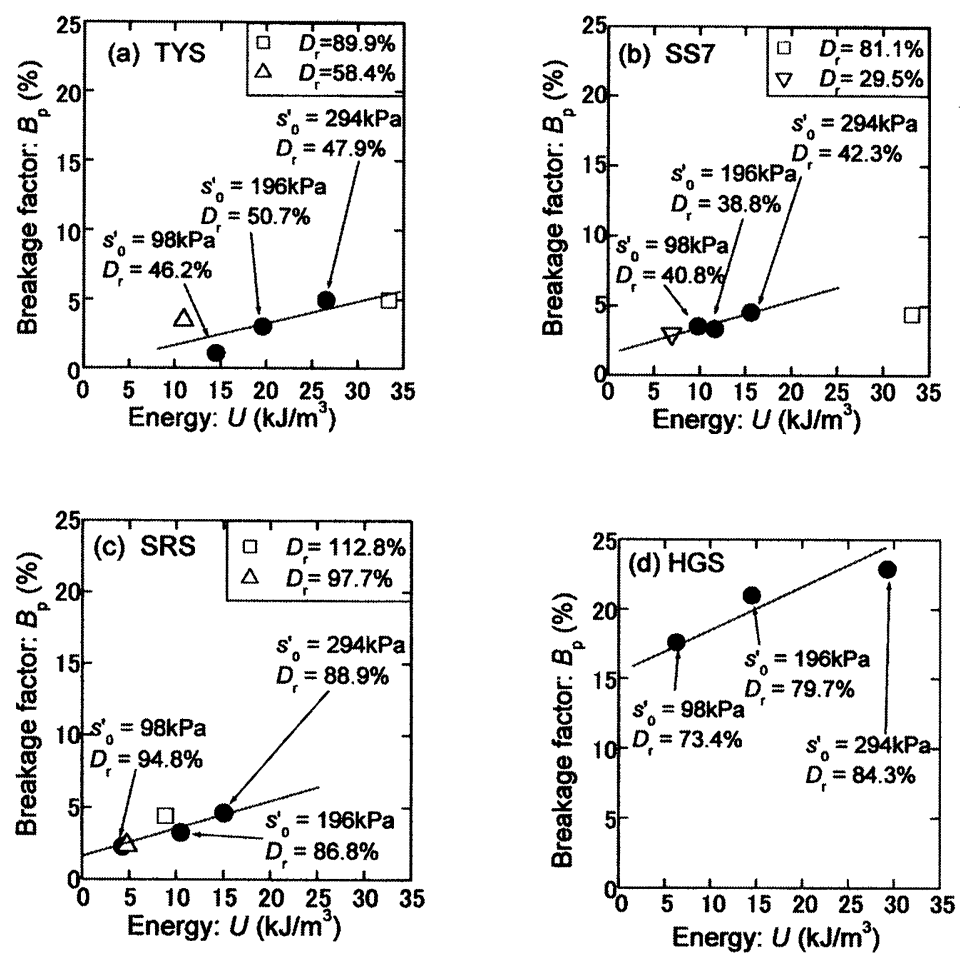

図一８各試料における粒子破砕係数とエネルギーUとの関係（D㤢密後の相対密度を示す）

Fig. 8 Relationship between particle breakage factor, $B_{p}$ and energy $U$ in the undrained triaxial shear tests $\left(D_{r}\right.$ is the relative density of specimen after consolidation) 
が見られる。図-8中のフィッティングラインの勾配 $\Delta B_{p} / \Delta U$ は破砕しやすさの指標と考えられ, 初期有効拘 束圧や相対密度とは無関係に, ある土では一定值となっ ていることが分かる。破砕しやすい試料の順序はHGS, SRS, SS7, TYSであることが示された。また, 図一 8 で，HGS，SRS及びSS 7 のフィッティングラインは原点 を通っていない。その理由のひとつとして，火山灰質土 の粒子集合体の分散によるものが考えられる（石川ほか, 2003)。

見かけの摩擦係数は，同じ軸ひずみ（最終軸ひずみ量 10\%）が生じた時の三軸試験結果に基づいて，式(4)を用 いて計算した。

$$
\tan \phi_{a} \approx \frac{t / s_{0}^{\prime}}{\sqrt{1+2 t / s_{0}^{1}}}
$$

ただし， $2 t$ は最終状態での軸差応力， $s_{0}^{\prime}$ は初期有効 拘束圧である。

\section{3 粒子破砕性による地すべり流動化への影響}

図-9は，粒子破砕のしやすさ $\Delta B_{p} / \Delta U$ と見かけの摩 擦係数 $\tan \phi_{\mathrm{a}}$ の関係である。まず, 各試料に対して, 初 期有効拘束圧が高いほど，見かけの摩擦係数が小さく なっている。また，最も破砕しやすいHGSとSRS試料は 見かけの摩擦係数はいずれの試験においても小さいこと から，有効拘束圧が低い条件のもとでも粒子破砕を生じ ることが推定できる。これらの結果は，実際に発生した 地すべりの体積と流動性との関係を説明でき，また，火 山灰などの粒子破砕しやすい斜面土層では，小さな規模 での流動性崩壊も頻繁に発生していることが説明できる。

以上の非排水せん断試験から，実施した試験の応力レ ベルの範囲内において，粒子破砕のしやすさを表す $\Delta B_{p}$ / $\Delta U$ は有効拘束圧や初期密度とは無関係に一定值と見 られる。粒子破砕しやすいほど，同等なせん断ひずみが 生じた時に，見かけの摩擦係数が小さくなる。また，有 効拘束圧レベルが高くなると，粒子破砕量が多くなるた め，粒子破砕しにくい斜面でも，地すべりの流動性が高

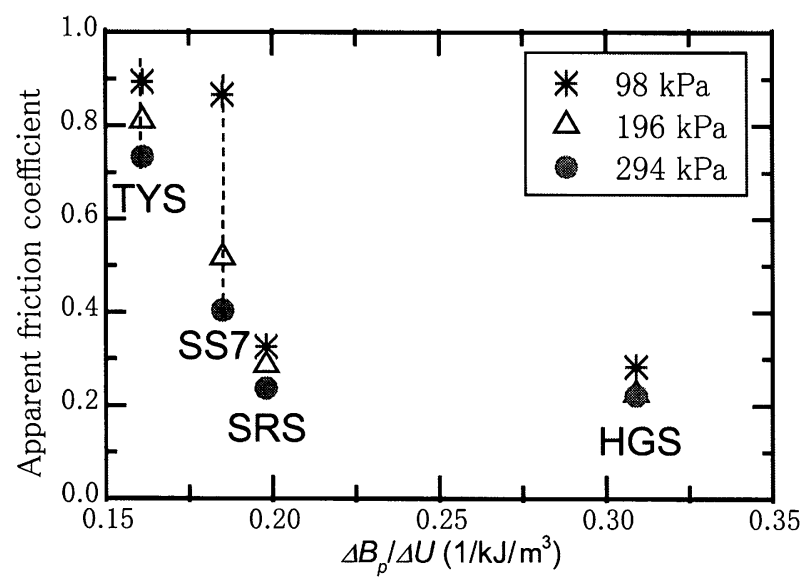

図ー9見かけの摩擦係数 $\tan \phi_{s}$ と粒子破砕しやすさ $\Delta \boldsymbol{B}_{p}$ IUUの関係

Fig. 9 The relationship between apparent friction coefficient $\tan \phi_{s}$ and grain crushing susceptibility $\Delta B_{p} / \Delta U$
くなることが考えられる。

\section{3. 改良型地すべり運動モデル}

地すべり運動範囲の予測は斜面防災において重要な課 題として位置付けられる。高速長距離運動地すべりの運 動機構を理解することで, 地すべり運動範囲予測の精度 向上が期待できる。これまで, Sassa（1988）をはじめ, Hungr（1995）及びMiao et al. (2001) により地すべり 運動予測のモデルがそれぞれ提案され，過去に発生した 地すべり事例を対象に，地すべり運動モデルを検証する ための事例研究が行われている。Sassa（1988）によっ て提案された地すべり運動モデルはすべり土塊の運動学 特性と流動化現象の連続性を考慮できる特徴を持つこと から，本論文ではこのモデルをべースにし，すべり面土 の抵抗変化を考慮できるように，改良を行った。

\section{1 地すべり運動モデルの概要}

Sassa（1988）は地すべり土塊に作用する力に基づい た運動方程式，及び運動中の体積変化が無いという前提 条件の連続方程式をべースとし，地すべり運動モデルを 提案した。図ー10は地すべりモデルと一つの土要素に作 用する力を示す。式 (5a)，(5b) 及び式(6)は $x, y$ 方向の 運動方程式と連続方程式である。運動方程式の右辺には, 重力項, 側面の土圧力項, 及び見かけの摩擦係数項が含 まれている。

$$
\begin{aligned}
& \frac{\partial M}{\partial t}+\frac{\partial}{\partial x}(u M)+\frac{\partial}{\partial y}(v M)=g h \frac{\tan \alpha}{q+1}-K g h \frac{\partial h}{\partial x}- \\
& \frac{g}{(q+1)^{1 / 2}} \cdot \frac{u}{\left(u^{2}+v^{2}+w^{2}\right)^{1 / 2}}\left\{h_{c}(q+1)+h \tan \phi_{a}\right\} \cdots(5 \mathrm{a})
\end{aligned}
$$

$$
\begin{gathered}
\frac{\partial N}{\partial t}+\frac{\partial}{\partial x}(u N)+\frac{\partial}{\partial y}(v N)=g h \frac{\tan \beta}{q+1}-K g h \frac{\partial h}{\partial y}- \\
\frac{g}{(q+1)^{1 / 2}} \cdot \frac{v}{\left(u^{2}+v^{2}+w^{2}\right)^{1 / 2}}\left\{h_{c}(q+1)+h \tan \phi_{a}\right\} \cdots(5 \mathrm{~b}) \\
\frac{\partial h}{\partial t}+\frac{\partial M}{\partial x}+\frac{\partial N}{\partial y}=0 \cdots \cdots \cdots \cdots \cdots \cdots \cdots \cdots \cdots \cdots \cdots \cdots \cdots(6)
\end{gathered}
$$

ただし，

$h:$ すべり土塊の厚さ；

$K:$ 水平土圧係数；

$M, N: x, y$ 方向における単位幅流量

$(M=u h, N=v h) ; u, v$ はそれぞれx,y方向の流 速;

$\tan \phi_{a}:$ すべり面見かけの摩擦係数；

$h_{c}$ : 粘着力項 $\left(c^{\prime}=\rho g h_{c}\right.$ のように定義される。長距離

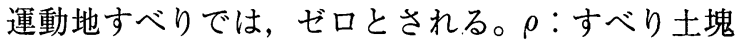
の密度, $g$ は重力加速度, $c^{\prime}$ は有効粘着力）;

$\tan \alpha, \tan \beta: x-z$ 平面及び $y-z$ 平面に扔けるすべり面の 傾斜 ;

$q=\tan ^{2} \alpha+\tan ^{2} \beta$;

$w=-(u \tan \alpha+v \tan \beta)$

式(5a)，(5b)と式(6)を平面座標系において有限差分 

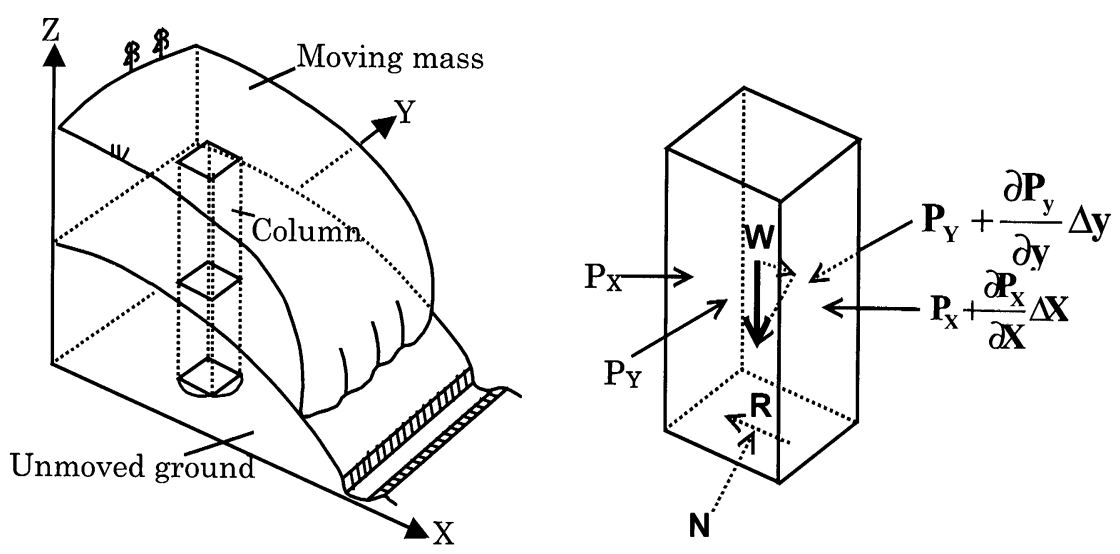

図ー10 地すべり運動のイメージ図（左）およびーつの要素に作用している力（右) (Sassa, 1988より)

Fig. 10 Landslide model (left) and forces acting on a column (right) (after Sassa, 1988)

化し，運動方程式より各メッシュへの流量を求め，それ を連続方程式に代入することによって，各メッシュ中心 のすべり土塊の厚さを求める。

\section{2 すべり面見かけの摩擦係数変化モデル}

Sassa（1988）の地すべり運動モデルでは，すべり面 のせん断強度とすべり土塊内部のせん断強度は区別され ている。ただし, $\tan \phi_{a}$ は一定值として入力される。実 際では, $\tan \phi_{a}$ は運動過程において変化していることが 想定される。Hungr（1995）のモデルにおいても，地す ベりは“すべり面”と“すべり土塊”の“二層構造”に モデル化されている（図-11）。この“二層構造”モデ ルにしたがって，以下のような仮定ができる。地すべり 運動過程において，“すべり土塊”の厚さが变化するが， せん断強度はあまり変化しない; そして，“すべり面”に 関しては，厚さを持っていないと仮定し，せん断強度の みが変化する。この仮定に基づいて，すべり土塊厚さの 変化に対応できる「すべり面見かけの摩擦係数変化モデ ル」を考案した。

Okada et al. (2000) は大阪層群の砂質土を対象に非 排水リングせん断試験を行った。試料は異なる初期応力 で圧密され, 長距離せん断後, 定常状態でのせん断抵抗 值は初期圧密応力と関係なく，ほぼ一定值になっている (図一12)。また, Wang and Sassa（2000）によるリン グせん断試験結果より，密な試料でも，せん断距離が 30 $\mathrm{mm}$ 超えると, せん断抵抗值はほほ定常状態になるこ とが示されている。この結果より, 長距離運動地すべり において，すべり面の土はほとんど定常状態になること が推定でき，そのせん断抵抗は上載のすべり土塊の厚さ と関係なく，一定值になることが仮定できる。

図ー13はすべり面見かけの摩擦係数変化モデルの概念 図を示す。図中, $B_{s s}$ は過唾間隙水圧蓄積率と呼ぶもの で, 地すべり運動中すべり面土の性質に依存する。乾燥 の場合, $B_{s s}=0$ であり, 完全飽和非排水の場合, $B_{s s}=$ 1.0になる。運動土塊のすべり面付近のせん断抵抗が定 常状態に到達するまでに，見かけの摩擦係数 $\tan \phi_{a}$ が小 さくなり，地すべり運動は加速運動となる。その後，垂

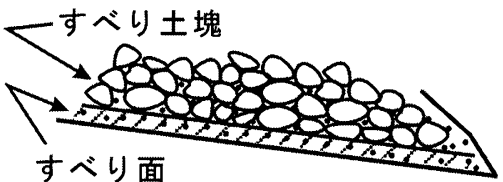

縦断面

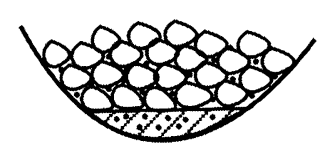

横断面

図ー11地すべりの二層構造（Hungr, 1995より）

Fig. 11 Two-layer structure of landslide (after Hungr, 1995)

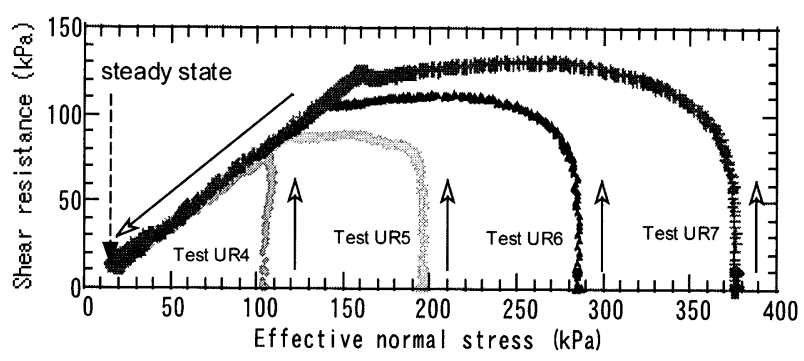

図一12 大阪層群の砂質土の異なる初期有効応力での非排水 リングせん断試験における有効応力経路

圧密後の間隙比は0.71に揃えた（Okada et al., 2000)

Fig. 12 The undrained ring shear test results on the coarse sandy soil of Osaka formation under different initial effective stresses. Void ratio after consolidation for all of the specimens was 0.71 (after Okada et al., 2000)

直応力の低下につれて，見かけの摩擦係数が大きくなり， 地すべり運動が減速して，最後に停止状態となる。これ らの関係は，式(7)，(8)，(9)で表される。四-14は，すべ り土塊の厚さの変化に伴う見かけの摩擦係数の変化を示 す。式(10)で表される臨界厚さはすべり面見かけの摩擦係 数が有効内部摩擦係数と等しくなる時のすべり土塊の厚 


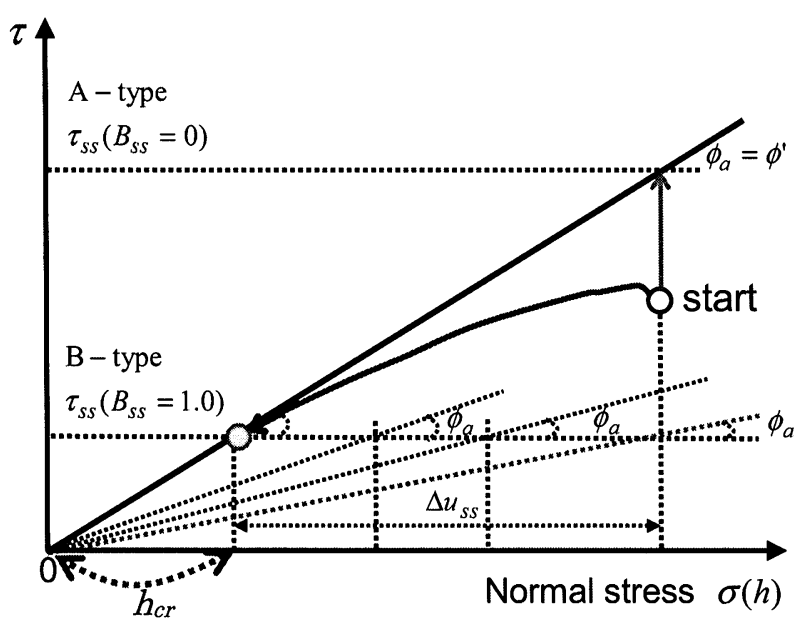

図一13 すべり面の見かけ摩擦係数変化モデル

Fig. 13 Model for change in the apparent friction coefficient

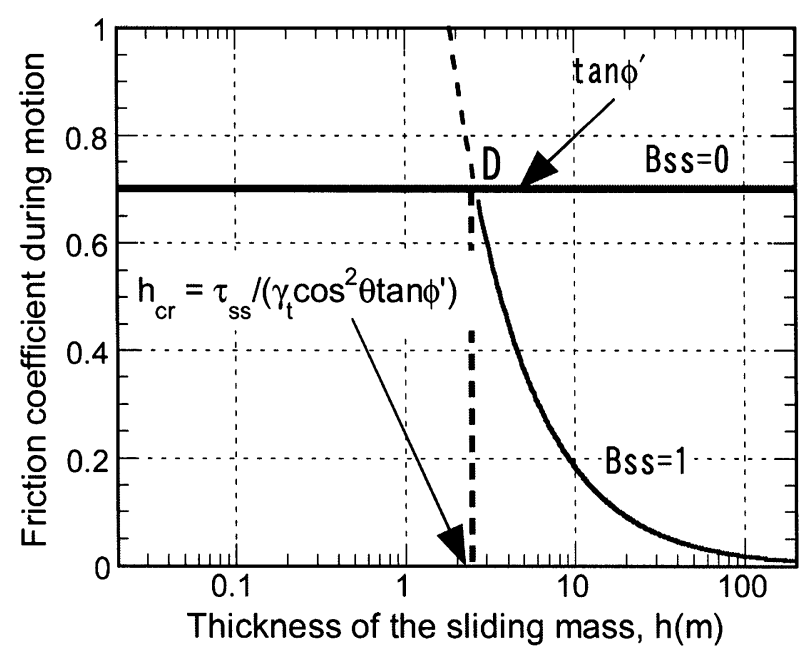

図ー14 すべり土塊の厚さの変化による見かけの摩擦係数の 変化

Fig. 14 Change of the apparent friction coefficient with the thickness of sliding mass

さである。すべり土塊の厚さが $h_{c r} よ り$ 小くなる時に, このモデルを使うと, すべり面ではサクションが働くこ とになってしまう。しかし，このようなことは実際あり えないことから，式(11)のように，制約条件を加え，すべ り土塊の厚さが臨界厚さより小さくなるとき，すべり面 見かけの摩擦係数が内部摩擦係数と等しくなるようにし た。

$$
\tau_{s s}\left(h, B_{s s}\right)=\tau_{s s}+\left(\sigma(h) \tan \phi^{\prime}-\tau_{s s}\right)\left(1-B_{s s}\right)
$$

ただし， $\tau_{s s}$ はすべり面土の定常状態でのせん断抵抗で

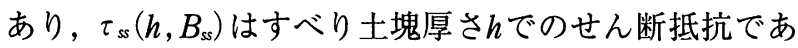
る。

$$
\begin{aligned}
& \sigma(h)=\gamma_{t} h \cos ^{2} \theta \\
& \tan \phi_{a}=\frac{\tau_{s s}\left(h, B_{s s}\right)}{\sigma(h)}
\end{aligned}
$$

$$
h_{c r}=\frac{\tau_{s s}}{\gamma_{t} \cos ^{2} \theta \tan \phi^{\prime}} \cdots \cdots \ldots \ldots \ldots \ldots \ldots \ldots \ldots \ldots \ldots(10)
$$

$\tan \phi_{a}=\tan \phi^{\prime}$, ただし, $h \leq h_{c r}$ の時に

\section{4. 地すべり運動シミュレーション}

「すべり面見かけの摩擦係数変化モデル」の有効性を 示すために, 安山岩質の渓床堆積物の上を長距離流下し た澄川地すべり及び火山灰質斜面で発生した稗返地すべ りを取り上げ，地すべり運動シミュレーションによる地 すべり運動・堆積範囲の検証を行った。

\section{1 秋田県澄川地すべり}

澄川地すべりは1997年 5 月11日に秋田県八幡平澄川温 泉で発生した。すべり土塊の一部は澄川にすべり込み， 直下の澄川温泉旅館ならびに下流1.2kmに位置する赤川 温泉旅館を破壊した後, さらに下流 $2 \mathrm{~km}$ にある砂防ダ 厶まで到達した。途中，国道341号線にある道路橋に大 きなダメージを与えた。幸いなことに，前兆現象に基づ いた地すべり予測ができたため，人的被害は発生しな かった（星野・浅井, 1997 ; 陶野ほか, 1997）。

この地域の地質状況については, Yanagisawa and Umemura（1999）によってまとめられている。新第三 紀のグリーンタフの上に, 澄川凝灰岩 (安山岩質), 秋 田一焼山熔岩が覆っている。澄川温泉の周辺では, 硫化 した土が分布していた。

地すべりの運動シミュレーションを実施するに当たっ て，以下のデータが必要となる。（1）すべり土塊の初期 厚さ；(2）すべり面の標高；（3）すべり面土及びすべり 土塊の物理・力学パラメー夕 (単位体積重量, 粘着力, 内部摩擦角, 定常状態でのせん断強度）及び（4）運動 経路における飽和条件・排水条件。

澄川地すべりに関しては，地すべり発生後，林野庁に よる詳細なボーリング調査が実施され，国土地理院 （1998）によって“八幡平澄川地すべり災害地形分類図” が発刊された。すべり面の標高データ及び地すべりの初 期厚さはこの地形分類図から読み取った。また，地すべ り発生直後，株アジア航測の空中写真判読より，地すべ りの運動範囲と堆積範囲も明確になっている。図ー15は 地すべりの堆積物の分布範囲を示す（千葉, 1998）。地 すべりの上部は20-40mの距離を運動して，停止した。 すべり土塊の先端部分は流動化現象が生じ, 澄川, そし て赤川を流下した。佐々ほか（1998）が澄川にある安山 岩質の渓床堆積物に対して実施した非排水載荷リングせ ん断試験により，澄川地すべりの高速運動メカニズムを 解明し，すべり面が細粒化したと推定した。この推定は 同じ安山岩質砂磁層で発生した出水市針原川の斜面崩壊 の再現試験より，確認された。図ー16は澄川から採取し た安山岩質の渓床堆積物に対して実施した速度制御非排 水リングせん断試験の応力経路を示す。この結果より, すべり面土の定常状態でのせん断抵抗 $(6.0 \mathrm{kPa})$, 内部 


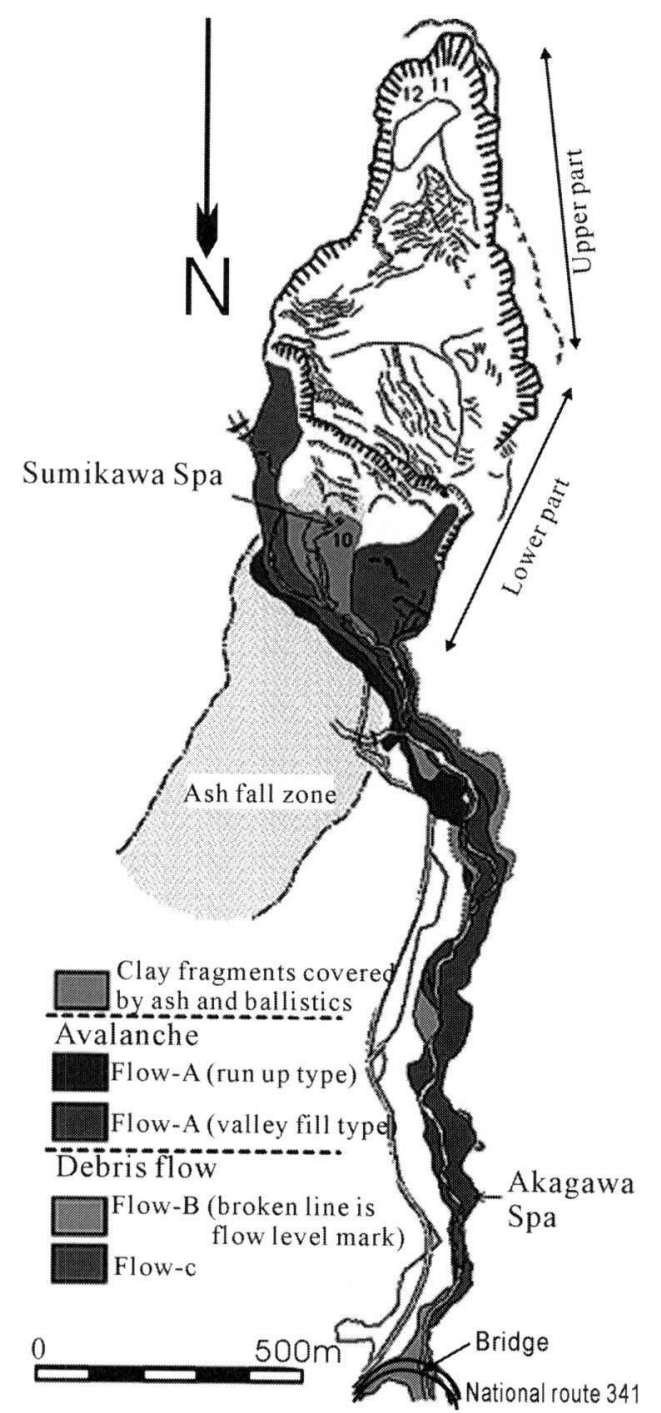

図一15 澄川地すべり堆積物の分布範囲（千葉, 1998)

Fig. 15 The deposition area of the Sumikawa landslide (after Chiba, 1998)

摩擦角 $\left(38.6^{\circ}\right)$, 有効粘着力 $(0 \mathrm{kPa})$ が決定できた。 また，地すべり発生域でのすべり面土については，すべ り土塊がすべり出すように，逆算法を用いて，初期の見 かけの摩擦係数を 0.15 と設定した。シミュレーションに 用いた土質パラメータは表- 2 にまとめている。

以上の地形, 上質力学パラメータに基づいて, 澄川地 すべりの運動シミュレーションを行った。澄川の渓床堆 積物が飽和されているので, “間隙水圧蓄積率 $B_{s s}$ ”を 0.95に設定した。図－17には，地すべり運動開始から2.3 秒後, 106. 4秒後, 及び停止時の757.2秒後の計算結果を 示す。すべり土塊の厚さを10倍に拡大して表示している。 このシミュレーションより得た地すべり運動範囲の結果 は実際に堆積した範囲, 特に運動距離と, ほほ一致して いることが分かる。

\section{2 稗返地すべり}

稗返地すべりは福島県西郷村に位置しており，1998年 8 月に福島県と栃木県の境界での豪雨によって, 発生し

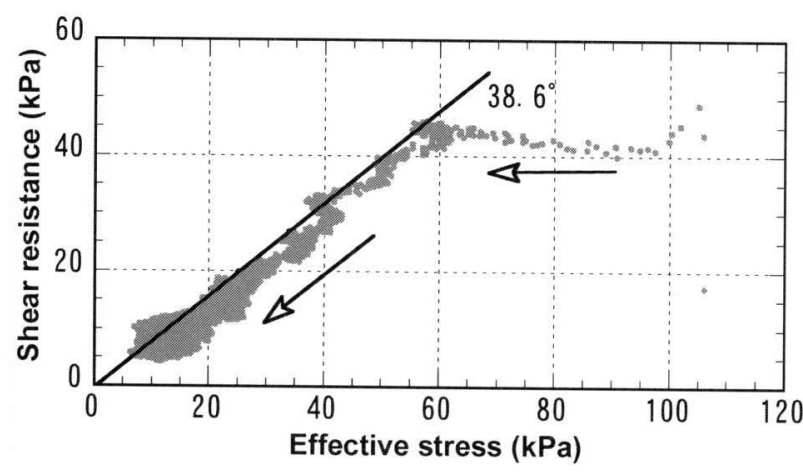

図一16 澄川の渓床堆積物の非排水リングせん断試験におけ る有効応力経路

Fig. 16 Effective stress path of the undrained ring shear test on the alluvial deposit in the Sumikawa torrent

表一２＼cjkstart澄川地すべりシミュレーションに用いた土質パラ xータ

\begin{tabular}{|l|c|}
\hline すべり土塊の単位体積重量 $\left(\mathrm{kN} / \mathrm{m}^{3}\right)$ & 20.0 \\
\hline 水平土圧係数 (全域) & 0.6 \\
\hline すべり土塊の粘着力 $(\mathrm{kPa})$ (全域) & 0.0 \\
\hline すべり土塊の内部摩擦係数 (全域) & 0.6 \\
\hline $\begin{array}{l}\text { すべり面の土定常状態でのせん断抵抗 }(\mathrm{kPa})(\text { 全 } \\
\text { 域) }\end{array}$ & 6.0 \\
\hline すべり面の粘着力 $(\mathrm{kPa})$ (全域) & 0.0 \\
\hline すべり面の有効摩擦係数 (全域) & 0.80 \\
\hline
\end{tabular}

た長距離運動地すべりである。図－18は地すべり源頭部 と堆積範囲のイメージ図を示す (Wang et al., 2002)。 地すべり運動土塊は全て源頭部からすべり出し, 平坦な 水田の中を運動し, 堆積した。見かけの摩擦角度は 11.2 度で, 高い流動性を示した。非排水三軸試験の結果に示 されたように，火山灰質土は粒子破砕しやすいため，地 すべり土塊の体積が小さいにもかかわらず，長距離運動 したと考えられる。

稗返地すべりの源頭部から採取した火山扊試料に対し て, 非排水リングせん断試験装置を用いて, 源頭部での 運動再現試験及び水田の上での運動再現試験をそれぞれ 行った。図ー19にはリングせん断試験の結果を示す。試 験の詳細については佐々ほか（2001）及びWang et al. （2002）を参照されたい。

リングせん断試験の結果に基づいて, 表一 3 のような パラメータを用いて，地すべり運動のシミュレーション を行った。図ー20は地すべり運動開始から1.6秒後, 6.8 秒後, 及び停止時の 177.3 秒後の計算結果を示す。運動 土塊の厚さは計算值の 5 倍にして表示している。地すべ り運動が停止した時に, 先端と源頭部の距離は約100メー トルとなり, 実際の地すべりの堆積範囲にほぼ一致して いる。眓ー21にはシミュレーションによる斜面横方向の 最大速度 $U_{\max }$ と斜面傾斜方向の最大速度 $V_{\text {max }}$ の時間的変 
Step : 200 Time $: 2.307 \mathrm{sec}$

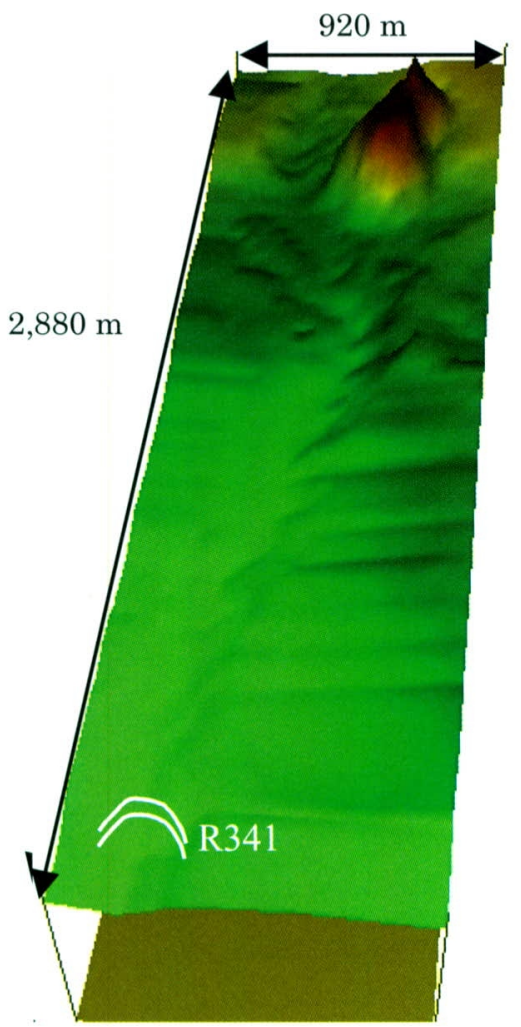

(a) $\mathrm{t}=2.3 \mathrm{sec}$
Step : 21000 Time : $106.435 \mathrm{sec}$

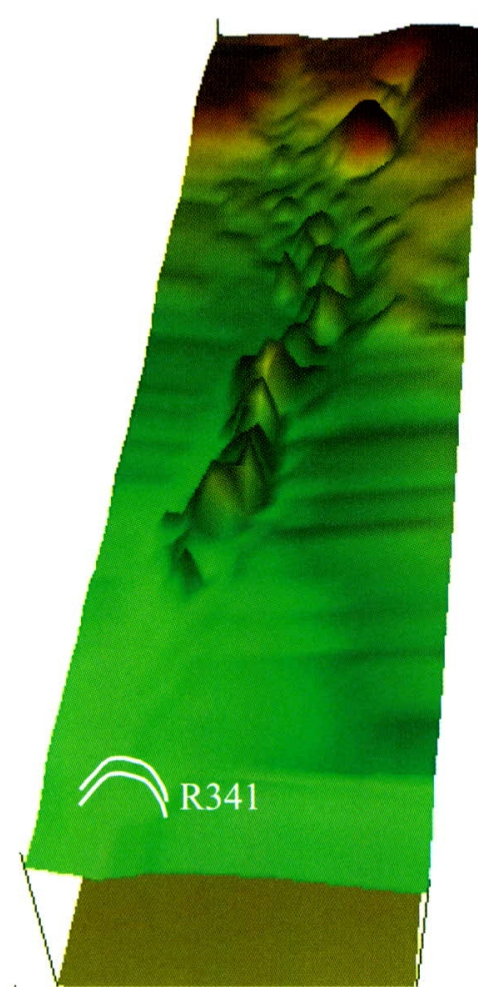

(b) $\mathrm{t}=106.4 \mathrm{sec}$
Step : 55600 Time : $757.196^{\mathrm{sec}}$

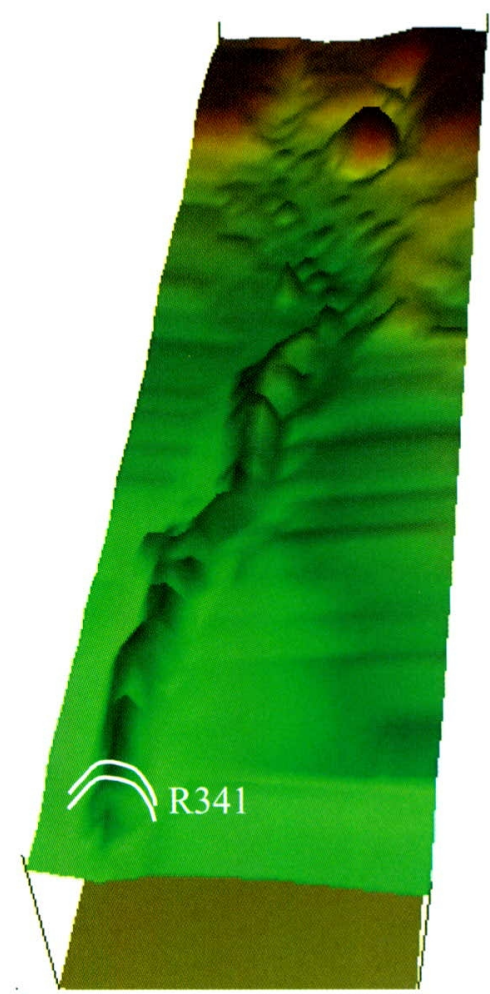

(c) $\mathrm{t}=757.2 \mathrm{sec}$

図ー17＼cjkstart澄川地すべりのシミュレーション結果（土塊厚さ：10倍）

Fig. 17 The simulation results on the Sumikawa landslide

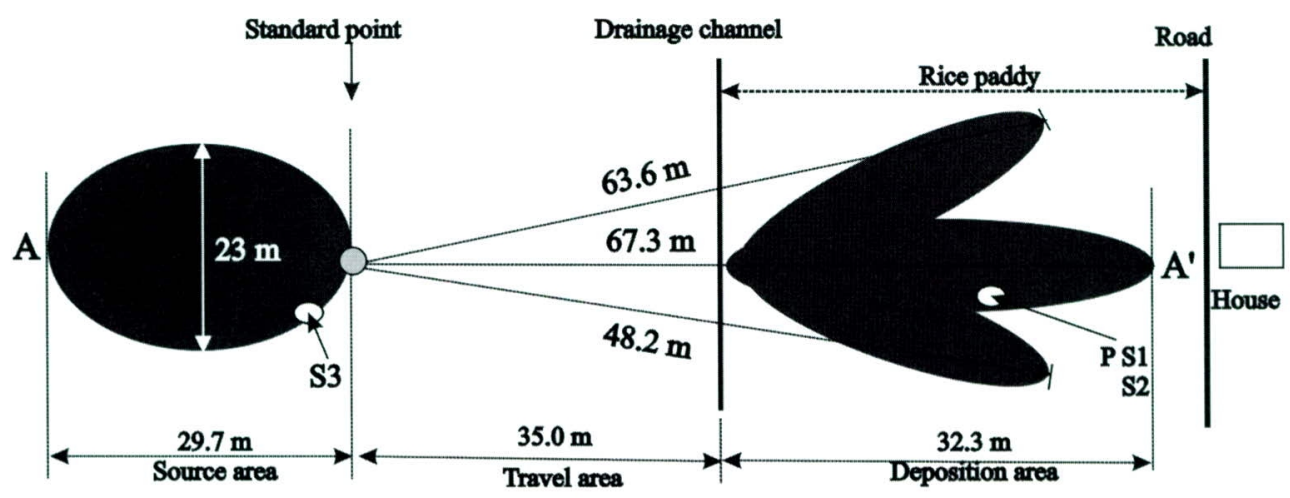

図一18 1998年福島県豪雨による稗返地すべりの堆積分布図 (Wang et al., 2002より)

Fig. 18 Plan sketch of the Hiegaeshi landslide triggered by the August 1998 heavy rainfall, Fukushima Prefecture (after Wang et al., 2002)

化を示す。地すべり運動の加速，減速及び停止過程を再 現できた。

以上に示す二例の運動シミュレーションより，改良し た地すべり運動シミュレーションのモデルは異なる地形 条件, 地すべり規模及び運動様式の地すべりに対する検 証ができたと思われる。ただし，今回の検証は運動範囲， 特に地すべり土塊先端の流下距離に着目しているが，さ らに土塊の堆積厚さ，運動速度，流下時間などについて も検討が必要である。
5. まとめ

1）異なる試料の非排水三軸せん断試験より，非排水せ ん断過程では，粒子破砕現象が発生した。粒子破砕 しにくい試料では，有効拘束圧が高くなると，粒子 破砕が起こるため, 見かけの摩擦係数が小さくなっ た。この試験結果から，地すべりの体積と見かけの 摩擦係数との統計関係を説明できる。

2 ) 粒子破砕しやすい火山灰などの試料では，定常状態 に達する時の見かけの摩擦係数が初期有効拘束圧と あまり関係ないことから，破砕性斜面地盤では，小 

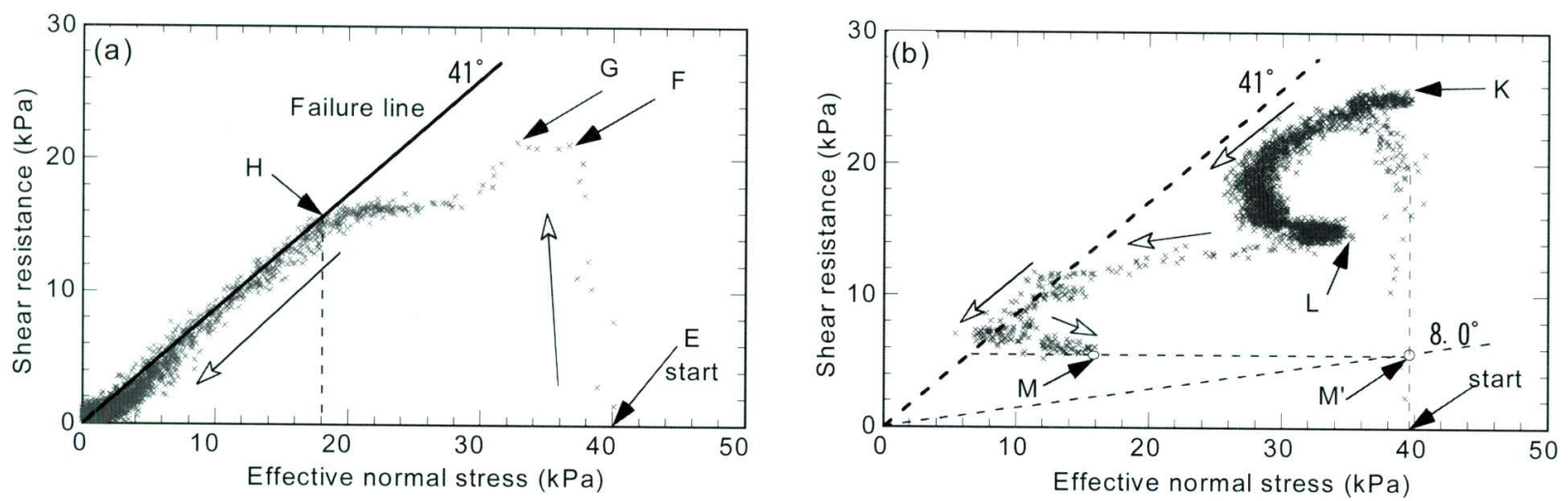

\section{図ー19 稗返し地すべりのリングせん断試験結果}

（a）源頭部から採取した試料に対するせん断試験；（b）運動土塊と稲とのせん断試験

Fig. 19 Effective stress paths of the ring shear tests on the Hiegaeshi landslide (a) On the soil sample taken from the source area; (b) On the debris and rice stubble taken from the rice paddy

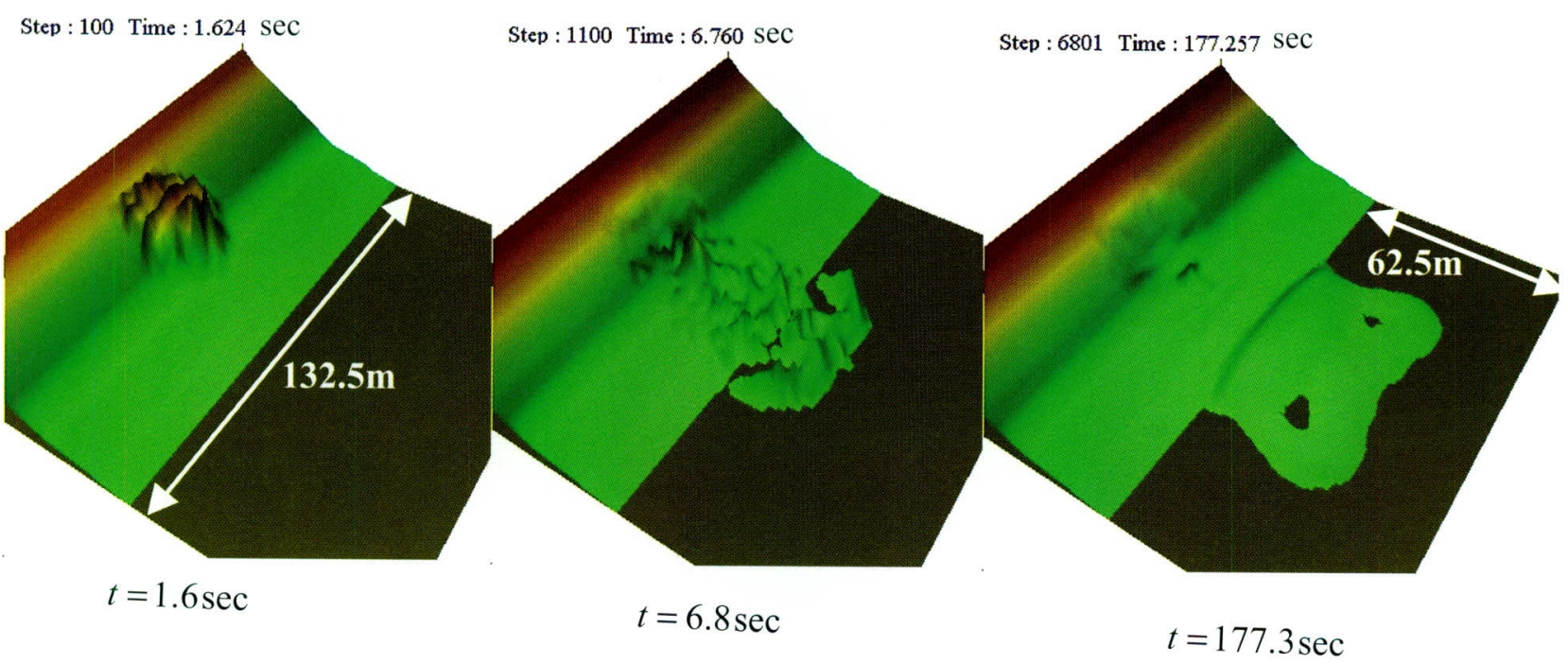

図一20 稗返地すべりのシミュレーション結果（土塊厚さ：5倍）

Fig. 20 Simulation result on the Hiegaeshi landslide

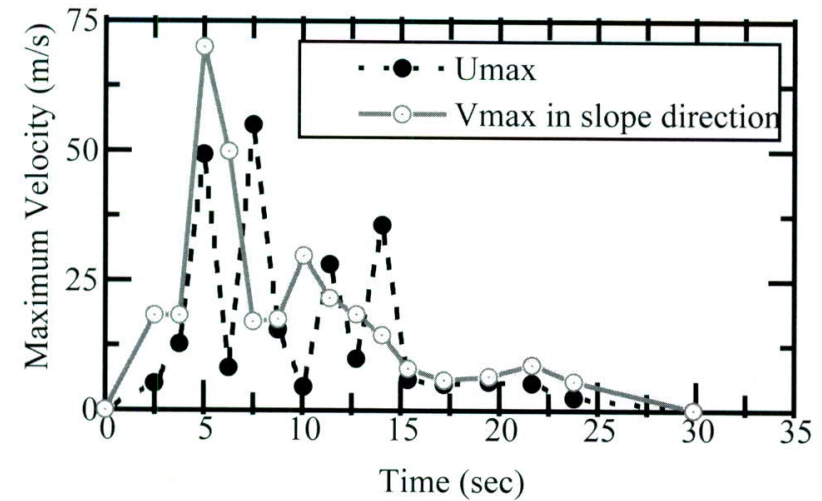

図ー21稗返地すべりシミュレーションのメッシュ最大速度 の変化

Fig. 21 Change of the maximum velocities in $x$ and $y$ directions in the simulation on the Hiegaeshi landslide
表ー3 稗返地すべりシミュレーションに用いた土質パラ x-タ

\begin{tabular}{|l|c|}
\hline すべり土塊の単位体積重量 $\left(\mathrm{kN} / \mathrm{m}^{3}\right)$ & 20.0 \\
\hline 水平土圧係数 & 0.6 \\
\hline すべり土塊の粘着力 $(\mathrm{kPa})$ & 0.0 \\
\hline すべり土塊の内部摩擦係数 & 0.6 \\
\hline $\begin{array}{c}\text { すべり面土定常状態でのせん断抵抗 } \\
\text { 源頭部・運動域 ( } \mathrm{kPa}) \\
\text { 水田 (稲と土塊) (kPa) }\end{array}$ & 0.5 \\
\hline すべり面の粘着力 (kPa) (全域共通) & 6.0 \\
\hline すべり面の有効摩擦係数 (全域共通) & 0.0 \\
\hline
\end{tabular}


規模の地すべりでも流動化現象が発生しうる。

3 ）澄川地すべり及び稗返地すべりを対象とした地すべ り運動シミュレーションでは実際の堆積範囲とほぼ 合致している結果が得られた。地すべり運動モデル (Sassa, 1988）に「すべり面見かけの摩擦係数変化 モデル」を導入することより，土質力学のパラメー 夕に基づいて，地すべり運動の加速，減速，そして 停止の過程を再現できた。

\section{謝辞}

本研究は文部科学省・科学技術振興調整費「地震豪雨 時の高速長距離土砂流動現象の解明」(代表者：佐々恭 二）及び金沢大学平成15年度重点化経費「破砕性地盤に おける高速土砂流動現象の発生機構及び運動予測」によ る助成を受けた。シミュレーションの実施に当たって， 京都大学防災研究所斜面災害研究センター福岡 浩助教 授にご助言を頂きました。また，三軸試験の実施及び デー夕整理において，金沢大学工学部平成13年度卒業生 前川丮一君と大元栄作君の協力を得た。記して，感謝の 意を表する。

\section{参考文献}

千葉達朗（1998）：熊沢地すべり土不流災害の概要。秋田県鹿角市 八幡平地すべり・土石流災慧に関する調查研究. 平成 9 年度 科学研究费補助金基盤研究 (C) 研究成果報告㫪（代表者: 柳沢栄闻), pp. 10-24.

Cubrinovski, M. and Ishihara, K. (1998) : Modeling of sand behavior based on state concept. Soils and Foundations, Vol. 3 , No. 3. pp. $115-127$.

星野 実・浅井健一（1997）：1997年 5 月八幡平澄川地すべり災害 (速報)。国土地理院時報，第88号，pp. 28-40.

Hungr. O. (1995) : A model for the runout analysis of rapid flow slides, debris flows, and avalanches. Canadian Geotechnical Journal, Vol. 32, pp. 610-625.

Hutchinson, J.B. and Bhandari, R.K. (1971) : Undrained loading, a fundamental mechanism of mudslide and other mass movement. Geotechnique, Vol. 21, No.4, pp. 353-358.

Ishihara, K. (1993) : Liquefaction and flow failure during earthquakes. Geotechnique, Vol. 43, No. 3, pp. 351-415.

石川祐治・汪発武・松本樹典（2003）：砂質士の粒子破砕しやすさ の定星的部俩。第38回地盤工学研究発表会発表講演集，秋田 市, pp. 401-402.
国土地理院（1998）：1997年八幡平澄川地すべり災害地形分類図.

Marsal, R. J. (1967) : Large scale testing of rockfill materials. ASCE Jour. of Soil Mech. and Found, Div., Vol.93 (SM 2 ). pp. $27-43$

Miao, T.D., Liu, Z.Y, Niu, Y.H, and Ma, C.W. (2001) : A sliding block model for the runout prediction of high-speed landslides. Canadian Geotechnical Journal, Vol. 38, pp. 217-226.

Okada, Y., Sassa, K., and Fukuoka, H. (2000) : Liquefaction and the steady state of weathered granite sands obtained by undrained ring shear tests: A fundamental study on the mechanism of liquidized landslides. Journal of Natural Disaster Science, Vol. 22, No. 2, pp. $75-85$.

奥田節夫（1984）：歴史記録から見た大崩壊の土石堆積状態の特性 京都大学防災研究所俰報, Vol.27, B-1, pp. 353-368.

Sassa, K. (1988) : Geotechnical model for the motion of landslides. Proc. 5th Int. Symp. on Landslides, Vol. 1, pp. 37-56.

Sassa, K., Fukuoka, H., Scarascia-Mugnozza. G. and Evans, S. (1996) : Earthquake-induced landslides: distribution. motion and mechanisms. Special Issue of Soils and Foundations, pp. $53-64$.

佐々恭二・福岡 浩・汪 発武 (1998)：秋田県澄川地すべり，鹿 愳島県針原川土石流に打ける高速長距離土塊移動のメカニズ ムについて．地すべり，Vol.35，No.2，pp.29-37.

Sassa, K. (2000) : Mechanism of flows in granular soils. Invited paper. Proc. GeoEng2000, Melbourne, Vol. 1, pp. 1671-1702.

佐々恭二・汪 発武・王 功輝 (2001)：1998年福島県降雨による 䄸返地区高速地すべりの運動機構. 土と基礎，Vol. 49, No.7, pp. $4-6$.

Skempton, A. W. (1954) : The pore-pressure coefficient A and B. Geotechnique, Vol.4, No. 4, pp. 143-147.

陶野郁雄・虺藤邦彦・伊藤 驍・千染達朗（1997）：秋田県鹿伊市 八幡平における地滑り・土石流災害現地調查.土と基礎, Vol. 45, No. 3, pp. 32-34.

Wang, F.W. and Sassa, K. (2000) : Relationship between grain crushing and excess pore pressure generation by sandy soils in ring-shear tests. Journal of Natural Disaster Science. Vol. 22, No. 2, pp. $87-96$.

Wang, F.W., Sassa, K. and Wang, G.H. (2002) : Mechanism of a long-runout landslide triggered by the August 1998 heavy rainfall in Fukushima Prefecture, Japan. Engineering Geology, Vol. 63, pp. $169-185$.

汪 発武・前川晃一・松本樹典（2002）：流動性地すべりに及ぼす 地盤破砕性の影響に関する試験的研究. 第41回日本地すべり 学会研究発表会講演集, 德島市, pp. 93-96.

Yanagisawa, E. and Umemura, J. (1999) : Geotechnical features of the Sumikawa landslide. Journal of Natural Disaster Science, Vol. 20, No. 2, pp. 83-92.

（原稿受付2003焦 7 月 3 日，原稿受理2003年11月18日） 